\title{
GPS 連続観測システムと光の応用
}

\section{GPS Earth Observation Network (GEONET) and its Application}

\author{
日下正明* . 宮崎真一* - 後藤勝広* - 畑 中雄樹* \\ Masaaki KUSAKA, Shin-ichi MIYAZAKI, Katsuhiro GOTOU \\ and Yuki HATANAKA
}

\section{1.はじめに}

国土地理院では, 高密度で高精度な測量網の構築と 広域的な地殻変動の検出を連続的に行うことを目的と し, 日本全国に GPS 固定観測局を展開し連続観測を 行っている。本稿では, この観測網について簡単に紹 介し，地殻変動やプレートテクトニクスにおけるこれ までの成果, その他の応用の一つとして RTK-GPS 測 量を取り上げ紹介する。

\section{GPS 連続観測システム}

国土地理院が日本全国を覆う GPS 観測網の構築を 開始したのは1994年だが, その 1 年前には, 地款変動 の監視を目的として関東・東海地域に110点からなる GPS 観測網が構築されていた。これらの 2 つのネット ワークは当初, 目的別・地域別に運用が行われていた が，1996年にこれらを統合し，現在は新たに追加され たものを含め約950点の電子基準点 (GPS 観測局)を擁 する，世界的にも他に類を見ない巨大な GPS 連続観 測システムとなり，GEONET(GPS Earth Observation Network) と名付けられた。

\footnotetext{
*国土地理院 Geographical Survey Institute テ305-0811つくば市北郷 1 番

「写真測量とリモートセンシング」VOL. 37, NO. 2, 1998
}

GPS 連続観測システムは, 日本全国の山間部を除い て約 $25 \mathrm{~km}$ 間隔に配置された観測点と, 観測点から公 衆電話回線を用いてデータを取得し解析計算を行う GPS 中央局により構成されている。

電子基準点には, 高さ $5 \mathrm{~m}$ のステンレス製ピラーが 設置され（図1)，その頂部には GPSのアンテナが取 ク付けられている。ピラーの中央部には GPS 受信機, 通信機器, 電源及び無停電用バッテリーが格納されて いる。また基礎部分は約 $2 \mathrm{~m}$ 立方のコンクリート基礎 が設置されており，一般地域において風速 $60 \mathrm{~m} / \mathrm{sec} の$ 強風に耐えられるよう設計されている。GPSによる観 測は, 2 周波, 上空視界 15 度以上, 30 秒サンプリング で24時間連続的に行っており，デー夕は一旦受信機内 のメモリに記録され後に中央局へ日々転送される。受 信機のメモリには約 10 日間分のデー夕を保持すること ができ, 通信障害等が起こった場合でも, 10 日以内に 通信が復旧すればデー夕の欠測を防ぐことができる構 造となっている。さらに，最大 10 時間までの停電に耐 えられるよう, 補助バッテリ一が備えており, 災害時 においても極力データの久测が起こらないような配慮 がなされている。

中央局（図 2 ）は, 茨城県つくば市の国土地理院内 にあり, 通信装置, デー夕格納装置, 解析装置及び統 合管理装置等をATM 方式による光 LAN で接続して いる。さらに，24時間のスケジューリングによる自動 運行システムが構築されており, 大量のデー夕を限ら れた時間内に処理できるようになっている。電子基準 点の観測データは, 一日一回電話回線で GPS 中央局 に転送され, RINEX II (Receiver Independent Exchange）フォーマットへの変換並びに品質検査を 


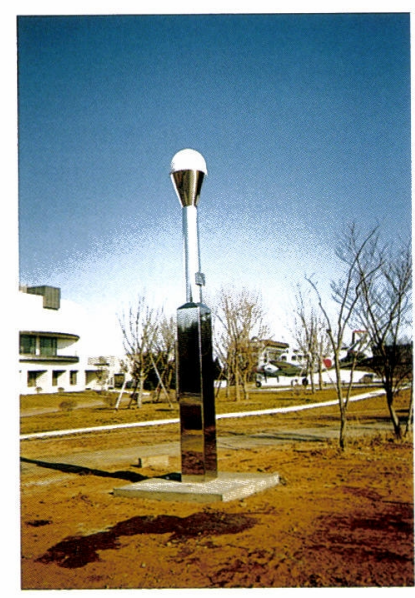

図 1 電子基準点

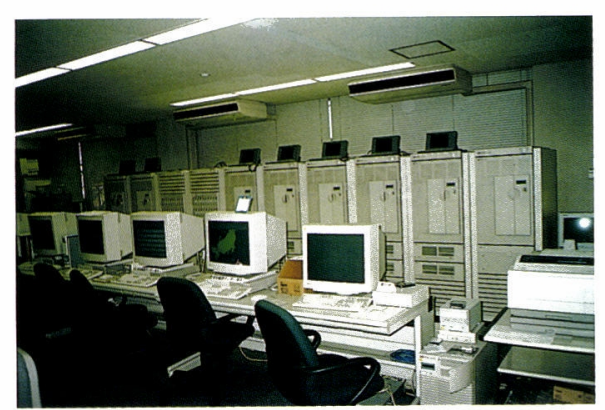

図 2 中央局 (茨城県つくば市国土地理院内)

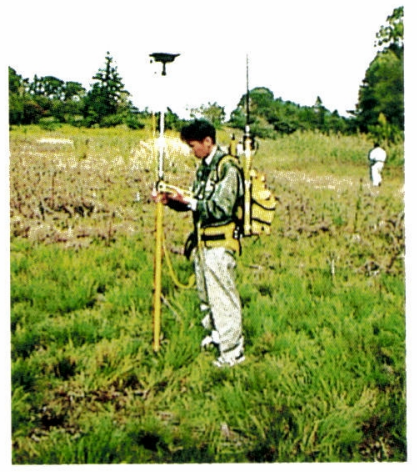

図 6 RTK 移動局での観測

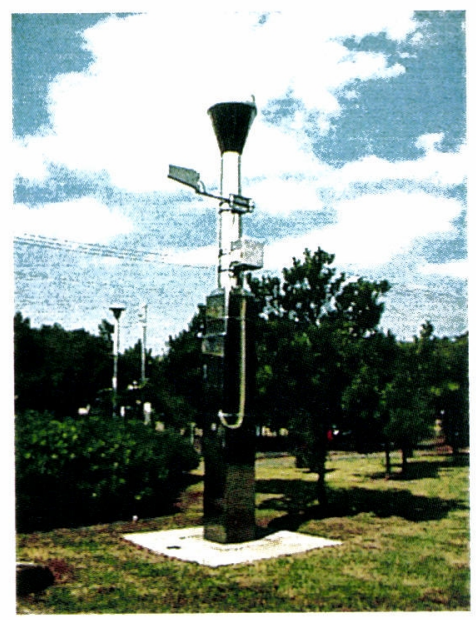

図7DMCA を取り付けた電子 基準点の外観 (千葉市)

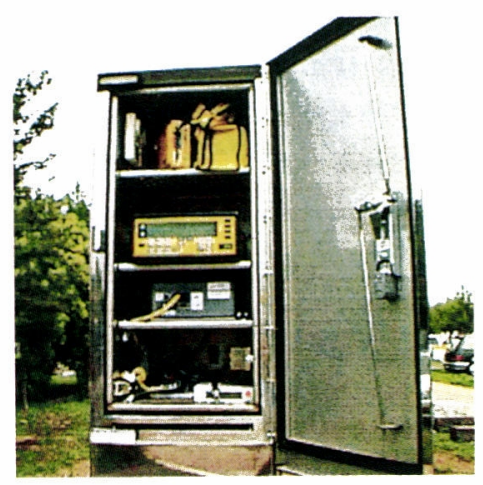

図 8 電子基準点の内部

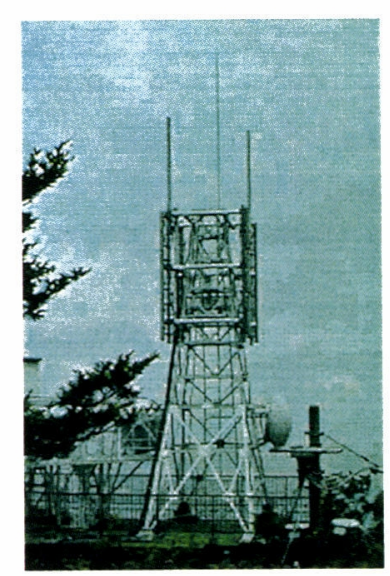

図10 無線制御局 (筑波山)

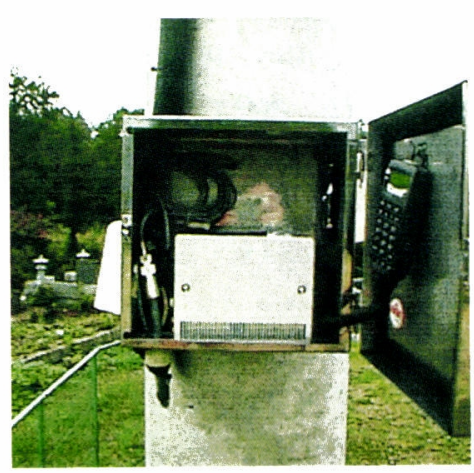

図 9 DMCA 無線装置 
経た後にデータベースへ格納される。解析計算は, 機 種別, 地域別にクラスターと呼ばれるブロックに分割 することにより, 解析計算時の異機種による影響を避 けると共に計算の高速化を図っている。解析計算のス トラテジーとしては速報的な計算を行う組み合わせ暦 (予報暦と速報暦を組み合わせた暦) と, より精密な軌 道情報を約 2 週間遅れで国際 GPS 地球力学事業から 入手して行う最終計算が定常ルーチンとして行われ， 解析された結果はSINEX (Software Independent Exchange) フォーマットに変換されデータベースに 格納される。現在, 解析計算には BERNESE, GAMIT, GIPSY といった学術用精密 GPS 解析ソフ トが使用されている。また, 解析結果は, 表示プログ ラムにより, 座標値・基線ベクトル成分（東西, 南北, 比高）の時系列表示, 変動ベクトル困, 歪み図等にし て端末装置へ表示し, 地殼変動（電子基準点の変動） の監視を行っている。これらの解析結果は地震調查委 員会, 地震予知連絡会議等一随時提出され重要な基礎 データとして利用される。

\section{GPS 連続観測網で得られた地殻変動}

GPS で得られた観測点座標を時系列として見ると 地款変動に関する情報が得られる。地表の観測点の地 殸变動速度は, 最も簡単には日々の観測点座標に対し て直線回帰を行うことによって得られる。国土地理院 の定常解析においては, 茨城県つくば市にある国土地 理院の構内にある観測点の座標を基準にしてその他の 観測点座標を推定している。したがって, 得られた速 度は全てつくば観測点が不同であると仮定して得られ たものになる。地殼変動の速度場は, 基準となる固定 点としてどこを選ぶかによって様相が変化してしま う。速度場に意味を持たせるためには，例えば，ある プレートに対する変動という形で速度場を推定すれば よい。Miyazaki and Hatanaka（1997）は一年間の観 測デー夕を用い, Heki (1996) によるVLBI データの 解析によって得られた「つくば」のユーラシアプレー トに対する運動を速度場に加え, ユーラシアプレート 安定部に対する変動として速度場を推定した。その結 果を，これまで提唱されてきたプレート境界と共に図 3 に示す。まず気がつくのは，これまで指摘されてき た糸魚川一静岡構造線を境界に速度場の構造が異なっ ている。しかし，GPSによる速度べクトルを見ると，
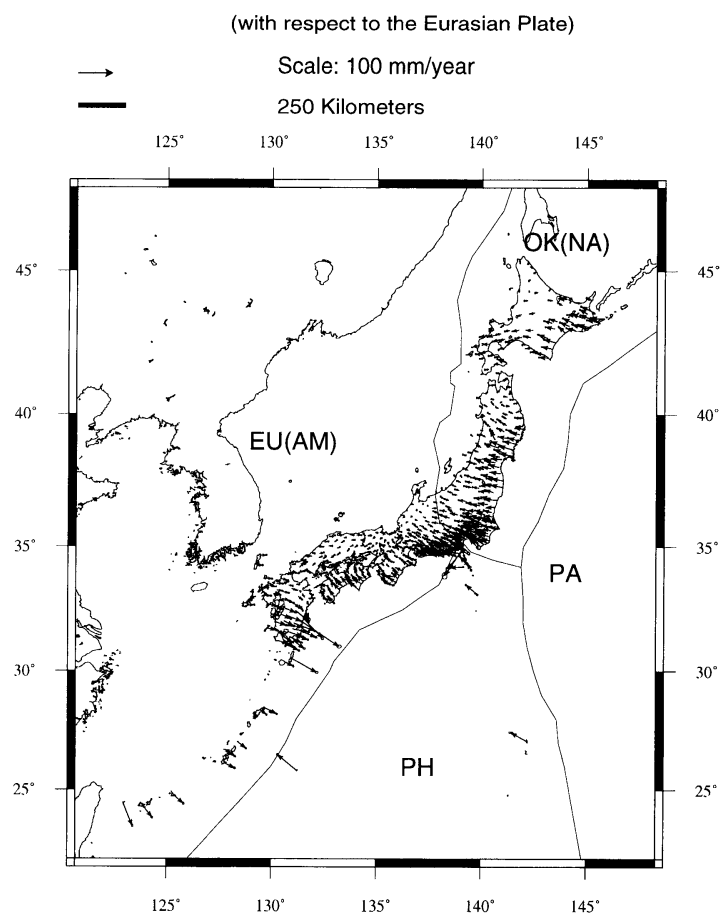

図 3 日本列島の地殼変動速度場

ベクトルの大きさが大きく変化するのは静岡から系魚 川へかけてではなく, 新潟かけてである。この結果は, 後者がプレート境界であるとする説（多田，1983）を 支持している。

このプレート境界で分かれる領域の西側 (西南日本) は, もともとユーラシアプレートに属すると考えられ ている。もしこの地域がユーラシアプレートに属する のであれば，速度べクトルはゼロになるはずである。 しかし図 3 を見ると, 中国地方かやら四国北部にかけ ては東向きに, 四国南部は北西方向に, 九州地方南部 は南南東へ変動している。中国地方の東進については 諸説ある。例えば, この地域が一つのアムールプレー トと呼ばれる小さなプレートとしてユーラシアプレー トとは独立に運動していると考えることもできる。四 国南部は，ユーラシアプレートの下に沈み込むフィリ ピン海プレートによるプレート同土の固着によって， フィリピン海プレートの運動に引きずられていること を反映している。連動の方向は Seno et al. (1993) で 推定されているフィリピン海プレートのユーラシアプ レートに対する相対運動の方向と良く一致している。 
九州南部では, 2 回の日向灘地震と鹿児島での地震に よる影響のため, 通常時とは異なる速度になっている ことに注意を要する。

一方の東北日本では，東北日本の下に沈み込む太平 洋プレートの西進の影響と考えられる西向きの変動が 顕著である。東北南部ではこの傾向が顕著で, プレ一 卜境界を形成すると考えられている東北南部太平洋沖 の日本海溝では, 四国沖と同様にプレート間の固着が 存在することが原因と考えられる。一方の東北北部で は，1994年に発生した三陸はるか沖地震の影響が 1 年 以上経過した現在でも残っており，プレート間の固着 が未だ回復していないと考えられている。さらにデー 夕の取得を続ければ，巨大地震のサイクルである，破 壊 (地震), 未固着, 回復, 固着の一連のプロセスを世 界で初めてとらえることになるだろう。北海道はより 複雑な様相を示している。東南部では太平洋プレート による影響が観測されているが，東北とは対照的にプ レート境界から遠ざかってもその大きさが減少しな い。特に興味深いのは，札幌付近に比較して奥尻島な どの南西沖では西向きの速度が大きくなっていること である。北海道南西沖地震の影響が深部においてまだ 残っている可能性もあるだろう。

ここまで見たように，速度場で見ている限りは固定 点の選択による任意性がある。そこで，次にこれをひ

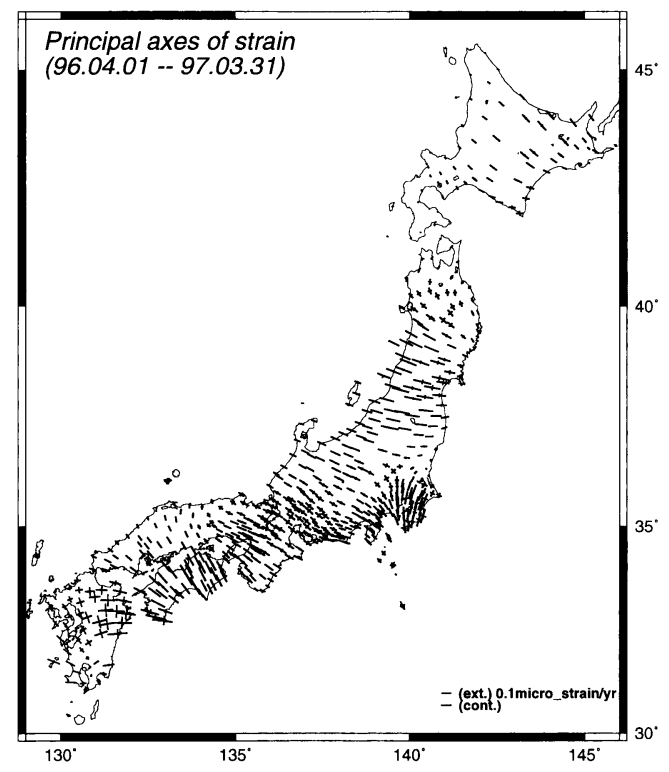

図 4 日本列島の地殼変動歪み速度場 (Kato, 1998による)
ずみ速度場に変換した結果を示そう。Uずみ速度場は 速度場の速度による空間微分なので, 速度の定数バイ アスが微分によってなくなり, 固定点の選択による任 意性はなくなる。しかし，Uずみの計算では，どこか 異常な観測点があれば，その観測点を含む領域全てで Uずみ速度の值が異常になる。そこで, Kato et al. (1998)は，最小二乗コロケーションと呼ばれる手法で 観測データをシグナルとノイズに分解し，シグナルの 部分に対してひずみ速度を計算した。罒4に主ひずみ を示す。この結果はさまざまな情報を我々に教えてく れる。例之ば，九州の雲仙一島原構造带において南北 伸張がみられること，四国から紀伊半島へ抜ける中央 構造線におけるせん断ひずみが大きいこと，などが見 られる。このような結果はこれまでの手法では10年， あるいは100年かかって得られてきたものであり，それ がわずか一年間で明らかにされてしまったわけであ る。

\section{4. 電子基準点を利用した RTK-GPS 測量}

RTK-GPS とは, リアルタイムキネマティック GPS の略で，干渉測位方式の一種である。RTK は，その名 のとおりリアルタイムに基準局のデータを移動局に伝 送し,移動局の位置を正確に割り出すシステムである。 従来測量の主流であったスタティック（静止）測量で は, 1 数時間の観測の後，デー夕を持ち寄り解析を 行って，位置を算出していた。いわゆる後（あと）処 理で新点の位置を求めていたのである。RTKを導入 することによって, 現場での結果の確認ができ, 作業 効率が格段に向上する。

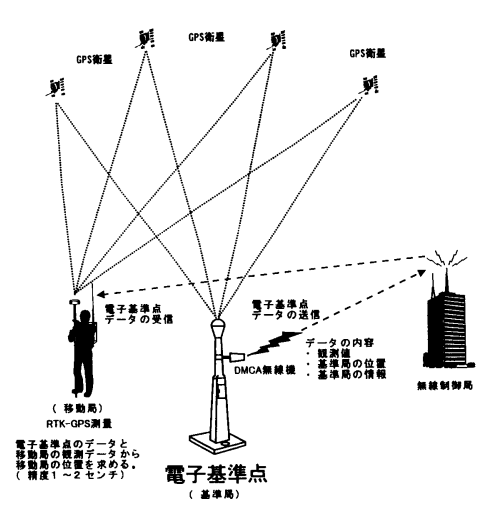

図 5 電子基準点を利用した RTK-GPS 測量 
国土地理院は, 郵政省と共同で電子基準点を利用し たRTK-GPSに関する公開実験を行っている(図 5 )。 この実験は平成 9 年 10 月から平成 10 年 3 月までの半年 間を予定し, 関東と関西のそれぞれ 6 点ずつの電子基 準点に DMCA 無線と呼ばれるデジタル移動通信装置 を設置している。電子基準点 (基準局)で受信した GPS データをユーザー（移動局）に常時伝送（放送）し, 移動局の位置をリアルタイムで求める。今後, 测位精 度の検証や受信範囲の状況など, 実験の結果を踏まえ， 実用化へ向けての検討を行う。

電子基準点の観測データを移動局に伝送する方法に は, 携帯電話, PHS, 専用線, 衛星通信などいろいろ と考えられる。データをいかに相手に正確に伝えるか が重要である。RTK が普及し始めた頃には, 免許の要 らない特定小電力無線を利用したものが主流であった が,「送受信範囲が狭い (100m 程度)」,「市街地での混 信が多い」など満足な観測条件が得られなかった。そ こで，その解決策を模索していた時に現れたのが，前 出の DMCA である。

DMCA 無線とは, ディジタル・マルチ・チャンネル・ アクセスの略で, 財団法人移動無線センターが運営す る移動体通信システムの一つである。タクシーや運送 業などで利用されている無線システムで, モデムを接 続することによって, GPS のデー夕を送受信すること ができる。一つの制御局での受信範囲は半経 $30 \mathrm{~km}$ で ある。(ただし，環境や場所によって異なる）

DGPS (Differential GPS：RTK が搬送波位相を利 用するのに対して，DGPS は疑似距離を利用する）で 採用されているRTCM フォーマットは米国海上電波 技術委員会が勧告するフォーマットで, データ量が非 常に多く，伝送するにはかなり高速なデータリンク装 置（モデム）が必要である。そこで，各社はもっとス リムなフォーマットをつくることにしのぎを削った。 本実験で採用したフォーマットは CMR (Compact Measurement Record）と呼ばれる必要最小限のデー 夕に絞った（RTCMの 3 分の 1) ものである。

RTK では, OTF (On The Fly) と呼ばれる高速バ イアス決定技術を使って初期化を行う。そのため, 移 動途中の受信中断による計測不能ということがなく なった。

RTKによる測位精度は, 公称 $2 \mathrm{~cm} \pm 2 \mathrm{ppm}$ とい われている。国土地理院の実験でスタティック測位と RTK の比較を行った結果では, 約 $15 \mathrm{~km}$ 以内の基線で
は誤差が距離に比例せず, 最大で水平 $3 \mathrm{~cm}$, 垂直 7 $\mathrm{cm}$ という結果であった。これは, 比較的受信状態 (GPS も DMCA も) のよい条件の下での結果である。 したがって, GPS の衛星の数や無線の受信が弱い場所 では,この限りではない。

電子基準点を利用した RTKは，基準点測量をはじ め以下のような用途に使用されることが尒想される。

・公共測量 (地籍調査, 数値地形測量)

・工事測量（道路，河川，港湾，空港など）

・GIS (地理情報システム)

・車両（タクシ一, バス, 救急車など）の移動体管理

・自動走行支援 (ITS)

- 船舶の接岸誘導

・地下埋設物の調査

・古墳・遺跡の調查

・レジャー（ゴルフ，登山など）

・スキーのコース設定

- 精密農業 (トラクターの無人運転, 農薬散布, 収穫 支援)

- 重機の無人管理

・遭難者の救助

・地滑り, 崩落の監視

- 老人徘徊, 迷子調査

- 事件事故現場検証

- 3 次元 $\mathrm{CG}$ の作成

\section{5.おわりに}

国土地理院の GPS 連続観測システムと, それに よって得られた日本の地款変動の様子, リアル夕イム キネマティック測量への応用を紹介した。GPS 連続観 測システムの応用分野は大変広く, ここで紹介したの はその内のごく一部であることを最後に記す。

\section{謝 辞}

東京大学地震研究所の加藤照之氏には, 図 4 の使用 を許可いただいたことを感謝します。

\section{文献}

Heki, K., Horizontal and vertical crustal movements from three-dimensional very long baseline interferometry kinematic reference frame: Implication for the reversal time scale revision, J. Geophys. Res., 101, 3187-3198, 1996. 
Miyazaki, S., and Y. Hatanaka, Crustal deformation observed by GSI's new GPS array, EOS Trans. Am. Geophts. Union, 78, S104, 1997.

多田堯, 日本地震学会講演予稿集, No. 2, B33, 1983.

Miyazaki, S., K. Heki., D. Dong, and G. An, Space geodetic etermination of the movement of the Amurian plate, eastern Asia, in preparation.

Seno. T, S. Stein, and A.E. Gripp, A model for the north of the Philippine Sea plate consistent with NUVEL-1 and geological data, J. Geophys. Res., 98, 17941-17948, 1993.

Kato, T., G.S. El-Fiky, E.N. Oware, and S. Miyaza$\mathrm{ki}$, Crustal strains in the Japanese Islands as deduced from GPS dense array, submitted to Geophys. Res. Lett. 